\section{Susceptibility of Hazelnut Cultivars to Filbertworm, Cydia latiferreana}

\author{
Ute Chambers ${ }^{1,2}$, Vaughn M. Walton, and Shawn A. Mehlenbacher \\ Oregon State University, Department of Horticulture, 4079 Agriculture and \\ Life Sciences Building, Corvallis, OR 97331
}

Additional index words. Corylus avellana, filbert, shell thickness, infestation, crop damage, plant resistance

\begin{abstract}
Filbertworm, Cydia latiferreana (Walsingham) (Lepidoptera: Tortricidae), is a key insect pest of hazelnuts in North America. Susceptibility to filbertworm was determined in 25 hazelnut cultivars represented by 44 trees at the USDA National Clonal Germplasm Repository in Corvallis, OR. In addition, shell thickness of 17 of the cultivars was measured at the thinnest and thickest points of the basal scar as well as at the side of the shell wall. Filbertworm infestation, which ranged from $2 \%$ to $89 \%$ per tree, as well as shell thickness varied significantly among the cultivars. Filbertworm infestation significantly increased with decreasing shell thickness at the basal scar, where filbertworm larvae typically penetrate the nut. The cultivar Siciliana had the overall thickest shells and lowest filbertworm infestation $(6 \% \pm 2 \%$ average for the cultivar), whereas 'Frango 2', 'Casina', and 'Daviana' had the thinnest shells and $76 \%, 55 \%$, and $82 \%$ infested nuts, respectively. Nut infestation was not correlated with the thickness of the side wall. Our data suggest that a thicker basal scar in hazelnut cultivars contributes to resistance against filbertworm infestation.
\end{abstract}

Corylus avellana L. (Fagales: Betulaceae), the European hazelnut, is the species commercially grown for its nuts. It exhibits great genetic diversity for plant size, growth habit, nut size and shape as well as shell thickness. Commercial hazelnut cultivars are bred for various traits, including precocity, high nut yield per tree, round shape, thin shells, and easy pellicle removal. Kernels 11 to $13 \mathrm{~mm}$ in diameter are ideal for processing, whereas larger nuts ( 14 to $23 \mathrm{~mm}$ or larger) are desired for direct table consumption (in-shell market). The United States accounts for 3\% to $5 \%$ of the world hazelnut production (Olsen, 2002a) and is the world's largest producer of nuts for the in-shell market followed by France and Italy (FAOSTAT, 2010). In 2009, 78\% $(33,250 \mathrm{t})$ of the U.S. hazelnut crop was sold as in-shell nuts (U.S. Department of Agriculture NASS, 2010). The leading cultivar for the world in-shell market grown in the United States is 'Barcelona', also known as 'Fertile de

Received for publication 11 May 2011. Accepted for publication 26 July 2011.

This research was made possible by funding from the Oregon Hazelnut Commission.

We thank the USDA National Germplasm Repository, Corvallis, OR, for their cooperation in this project, in particular Kim Hummer and Joseph Postman. We gratefully acknowledge Joseph Postman and Callie Baker (Washington State University, Tree Fruit Research and Extension Center, Wenatchee) for critical comments on earlier drafts of this manuscript. Many thanks are also due to Mike Reitmajer, Betsey Miller, and Drew Mahedy for their technical assistance.

${ }^{1}$ Current address: Washington State University, Tree Fruit Research and Extension Center, 1100 N. Western Avenue, Wenatchee, WA 98801.

${ }^{2}$ To whom reprint requests should be addressed; e-mail uchambers@wsu.edu.
Coutard' in France and 'Castanyera' in Spain. 'Daviana'. The second most common in-shell cultivar in the United States is 'Ennis' with its pollenizer 'Butler', both selected and grown in the Pacific Northwest (Lagerstedt, 1980). In addition to large kernels, thinner shelled nuts are preferred for table consumption because they break more easily (Valentini et al., 2006). Selection for such favorable traits can, however, have unintended consequences that may include increased susceptibility to pests or diseases (Robinson, 1996).

A major insect pest in hazelnut orchards in North America is the filbertworm, Cydia latiferreana (Walsingham) (Lepidoptera: Tortricidae) (AliNiazee, 1998; Dohanian, 1940). This moth causes hazelnut growers substantial expense in terms of control costs, which amounted to $\approx$ U.S. $\$ 2.2$ million in 2006 (Julian et al., 2008). Additional revenue losses for growers arise from the costs of sorting infested from sound nuts and rejected loads when the number of infested nuts exceeds the economic threshold of $1 \%$ (Olsen, $2002 \mathrm{~b}$ ). The filbertworm is native to North America and occurs in acorns and galls of Oregon White Oak (Quercus garryana Dougl. ex Hook), wild hazelnuts [Corylus californica (A. DC.) Rose], and Catalina cherries (Prunus lyonii Sargent) (Dohanian, 1940). With the commercial introduction of hazelnuts to the United States in the early 1900s (Dohanian, 1940), C. latiferreana found it a suitable host and is now a key pest in hazelnut orchards.

In Oregon, where $99 \%$ of the U.S. hazelnuts are produced (Olsen, 2002a), filbertworm larvae infest hazelnuts throughout nut development and maturation from June through September (Walton and Chambers, unpublished data). During that period, females lay The leading pollenizer of this cultivar is eggs on leaves near nut clusters or directly onto the nuts. Nuts are borne in clusters of one to 12 , each enclosed in a husk, which attaches to the top of the nut, the basal scar. After hatching, the neonate larvae find their way through the soft part of the husk to the basal scar of the developing nut. When the basal scar is reached, the larvae tunnel about until the micropyle is located. The micropyle is the soft spot in the center of the basal scar through which neonate larvae typically enter the nut (Thompson, 1941). Inside the nut, larvae feed on the kernel causing damage. Late-instar filbertworm larvae exit the nut either through the widened entry hole at the basal scar or through a new exit hole in the side of the nut in soft-shelled varieties (Thompson, 1941). Emerging larvae drop to the ground where they overwinter and pupate in the spring (AliNiazee and Kelly, 1981; Dohanian, 1940; Thompson, 1941). In untreated orchards, $20 \%$ to $50 \%$ of the nuts can become infested with filbertworm larvae (AliNiazee, 1983; Walton and Chambers, unpublished data)

Hazelnut cultivars and new breeding selections are ranked for their resistance or susceptibility to various diseases and pests. These include eastern filbert blight caused by Anisogramma anomala (Peck) E. Müller, bacterial blight caused by Xanthomonas corylina Dowson, big bud mite (primarily Phytoptus avellanae Nal.), and filbert aphid (Myzocallis coryli) (Gantner, 2005; Lagerstedt, 1980; Pinkerton et al., 1993). In an early study of 16 commercial cultivars in Oregon, Dohanian (1944) briefly reported that filbertworm strongly favored some pollenizers over the main cultivar being grown for market, particularly noticeable when comparing 'Daviana' to 'Barcelona'. However, no comprehensive and detailed information is available that compares the susceptibility of hazelnut cultivars to filbertworm infestation.

In this study, we present cultivar-specific susceptibility of hazelnuts to filbertworm during one season in Oregon and correlate it to shell thickness at maturity. This study was conducted at the USDA National Clonal Germplasm Repository (NCGR) in Corvallis, $\mathrm{OR}$, which maintains a living collection of more than 700 trees (accessions) representing world diversity for the genus Corylus, including over 400 cultivars and selections of C. avellana (USDA-NPGS, 2011). Several cultivars are included in the collection under different names, which Boccacci et al. (2006) and Gökirmak et al. (2009) showed to be synonyms (Table 1). The USDA-NCGR hazelnut collection provided the unique setting for our study with hazelnut trees grown under the same climatic and management conditions and exposed to pest pressure for multiple years.

\section{Material and Methods}

Nut sampling. Hazelnuts from randomly chosen cultivars were collected at the NCGR in Corvallis, OR. Trees sampled were 18 to 27 years old planted $3.5 \mathrm{~m}$ apart in rows spaced $4.9 \mathrm{~m}$ apart. The NCGR hazelnut planting had 
Table 1. Filbertworm infestation in 44 accessions representing 25 hazelnut cultivars at the USDA National Clonal Germplasm Repository in Corvallis, OR. ${ }^{z}$

\begin{tabular}{|c|c|c|c|c|c|c|c|c|c|c|}
\hline \multirow[b]{2}{*}{ Cultivar $^{y}$} & \multirow[b]{2}{*}{ Accession $^{y}$ (synonym) } & \multirow[b]{2}{*}{$\begin{array}{l}\text { Total nuts } \\
\text { examined }\end{array}$} & \multirow{2}{*}{$\begin{array}{l}\text { Number of } \\
\text { infested } \\
\text { nuts }^{x}\end{array}$} & \multirow{2}{*}{$\begin{array}{c}\text { Number of } \\
\text { uninfested } \\
\text { nuts }\end{array}$} & \multirow{2}{*}{$\begin{array}{l}\text { Number } \\
\text { of blank } \\
\text { nuts }\end{array}$} & \multirow{2}{*}{$\begin{array}{l}\text { Percent } \\
\text { infested } \\
\text { nuts }^{\mathrm{w}}\end{array}$} & \multirow{2}{*}{$\begin{array}{l}\text { Mean percent } \\
\text { cultivar } \\
\text { infestation }\end{array}$} & \multicolumn{3}{|c|}{ Shell thickness $(\mathrm{mm})$} \\
\hline & & & & & & & & Micropyle & $\begin{array}{l}\text { Basal scar } \\
\text { maximum }\end{array}$ & $\begin{array}{l}\text { Side wall } \\
\text { (median) }\end{array}$ \\
\hline Barcelona & PI 557037 & 300 & 83 & 181 & 36 & 31 & & $0.95 \pm 0.15$ & $1.37 \pm 0.19$ & $1.50 \pm 0.35$ \\
\hline Barrettona & PI 617241 & 679 & 180 & 413 & 86 & 30 & & & & \\
\hline Butler & PI 557077 & 200 & 135 & 16 & 49 & 89 & & $0.73 \pm 0.08$ & $1.12 \pm 0.12$ & $1.58 \pm 0.46$ \\
\hline Casina & PI 617190 (Amandi) & 300 & 122 & 100 & 78 & 55 & & $0.61 \pm 0.11$ & $0.90 \pm 0.13$ & $0.89 \pm 0.23$ \\
\hline Closca Molla & PI 557109 & 200 & 81 & 66 & 53 & 55 & & $0.65 \pm 0.13$ & $0.94 \pm 0.16$ & $0.89 \pm 0.27$ \\
\hline Contorta & PI 557049 & 107 & 43 & 35 & 29 & 55 & & $0.74 \pm 0.11$ & $1.10 \pm 0.21$ & $1.08 \pm 0.20$ \\
\hline Cosford & PI 557039 & 200 & 164 & 30 & 6 & 85 & & & & \\
\hline Cosford & PI 557152 (Multiflora) & 200 & 148 & 47 & 5 & 76 & & & & \\
\hline Cosford & PI $617192\left(\right.$ Petoka $\left.^{v}\right)$ & 200 & 142 & 58 & 0 & 71 & $77 \pm 4 d$ & & & \\
\hline Daviana & PI 557040 & 200 & 145 & 32 & 23 & 82 & & $0.62 \pm 0.07$ & $0.94 \pm 0.13$ & $1.04 \pm 0.23$ \\
\hline Ennis & PI 557045 & 200 & 66 & 127 & 7 & 34 & & $0.87 \pm 0.11$ & $1.26 \pm 0.13$ & $1.18 \pm 0.27$ \\
\hline Garrofi & PI 557165 & 245 & 38 & 169 & 38 & 18 & & $0.94 \pm 0.10$ & $1.33 \pm 0.12$ & $1.08 \pm 0.25$ \\
\hline Giresun 54.001 & PI 557425 & 200 & 122 & 69 & 9 & 64 & & $0.83 \pm 0.12$ & $1.27 \pm 0.16$ & $1.23 \pm 0.25$ \\
\hline Giresun 54.042 & PI 557062 & 200 & 98 & 54 & 48 & 64 & & & & \\
\hline Giresun 54.050 & PI 557065 & 300 & 61 & 211 & 28 & 22 & & & & \\
\hline Lambert Nut & PI 617174 (Aveline Rouge) & 94 & 14 & 37 & 43 & 27 & & & & \\
\hline Lambert Nut & PI 271110 (Pellicule Rouge) & 280 & 107 & 112 & 61 & 49 & & $0.67 \pm 0.07$ & $0.93 \pm 0.11$ & $1.01 \pm 0.18$ \\
\hline Lambert Nut & PI 557088 (While Filbert) & 84 & 17 & 43 & 24 & 28 & $35 \pm 7 \mathrm{bc}$ & & & \\
\hline Lenka 3 & PI 617233 & 300 & 150 & 113 & 37 & 57 & & $0.70 \pm 0.10$ & $1.08 \pm 0.14$ & $1.05 \pm 0.26$ \\
\hline Lenka 4 & PI 617234 & 300 & 216 & 46 & 38 & 82 & & & & \\
\hline Nixon & PI 557138 & 444 & 243 & 166 & 35 & 59 & & $0.81 \pm 0.10$ & $1.47 \pm 0.19$ & $1.28 \pm 0.32$ \\
\hline Romische Nuss & PI 557208 (Fruttogrosso) & 300 & 54 & 234 & 12 & 19 & & & & \\
\hline Romische Nuss & PI 557211 (Payrone) & 200 & 58 & 136 & 6 & 30 & & $1.02 \pm 0.13$ & $1.39 \pm 0.20$ & $1.30 \pm 0.36$ \\
\hline Romische Nuss & PI 557171 & 200 & 54 & 119 & 27 & 31 & $27 \pm 4 b$ & & & \\
\hline Siciliana & PI 557215 (Minnolara) & 300 & 16 & 260 & 24 & 6 & & $1.02 \pm 0.10$ & $1.74 \pm 0.22$ & $1.94 \pm 0.52$ \\
\hline Siciliana & PI 557028 (Montebello) & 279 & 31 & 172 & 76 & 15 & & & & \\
\hline Siciliana & PI 557217 (Racinante G) & 202 & 3 & 185 & 14 & 2 & & & & \\
\hline Siciliana & PI 557175 (Siciliana) & 300 & 16 & 278 & 6 & 5 & $6 \pm 2 \mathrm{a}$ & & & \\
\hline
\end{tabular}

${ }^{\mathrm{z}}$ Infestation is averaged $( \pm \mathrm{SE})$ for cultivars with multiple trees. Shell thickness (mean $\pm \mathrm{SD}$ ) was measured at four locations on the nut (Fig. 1) for 19 accessions (17 cultivars). The two side wall measurements are combined.

${ }^{y}$ Names of cultivars and synonyms are from Gökirmak et al. (2009).

${ }^{\mathrm{x}}$ Infested nuts are nuts harboring filbertworm larvae as well as nuts with exit holes but no larvae present.

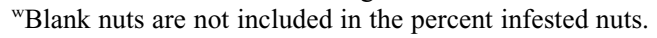

vabel in field collection shown to be incorrect by Gökirmak et al. (2009).

not been treated with insecticides for at least 5 years. Nuts were collected from 44 different accessions representing 25 cultivars. All currentseason nuts were collected underneath each tree canopy between 1 and 10 Oct. 2008. The hazelnuts were then returned to the laboratory and stored at $2{ }^{\circ} \mathrm{C}$ for up to 1 month until examination.

Nut examination. Nuts in each tree were classified as follows: 1) nuts containing filbertworm larvae; 2) nuts with filbertworm exit holes as sign of infestation but without larvae; 3) uninfested nuts; and 4) blanks (nuts without kernels). Initially, all nuts per tree sample were examined. As a result of the large number of nuts collected, the processing time for a complete tree sample was prohibitive. Hence, to accelerate the process, we took random subsamples of 200 to 300 nuts per tree. Tree samples with fewer than 200 nuts were completely examined, whereas samples with less than 40 nuts were not included in the analyses. Shell thickness was determined for a subset of 19 trees (one tree of each of 17 cultivars plus two additional trees for 'Siciliana' because of its low infestation level). Of the cracked nuts, 30 shell halves were randomly taken from each tree sample to determine the shell thickness using a handheld micrometer. The shell wall thickness was measured at four different positions: the thickest point of the basal scar, the micropyle (where the basal scar is the thinnest), and two points on the side wall (Fig. 1). Only shell halves with all four measurement positions intact were used.

Data analysis. Percentage filbertworminfested nuts was calculated from the total number of nuts examined excluding the number of blank nuts. Differences in percentage of infested nuts among cultivars were tested using the Kruskal-Wallis test and between cultivars using one-way analysis of variance and Fisher's least significant difference test. Differences in average shell thickness among cultivars were analyzed using the KruskalWallis test. Pearson's correlation coefficients were calculated for the percentage infestation and the shell thickness parameters. Regression analysis was used to determine if there was a linear relationship with the proportion of 
infested nuts as the dependent variable (y-axis) and shell thickness as the independent variable (x-axis). All analyses were performed in SigmaPlot (Sigmaplot 11.0; Systat Software, Inc., San Jose, CA).

\section{Results}

Filbertworm infestation was not concentrated along the borders or clumped within the NCGR hazelnut planting, and highly infested trees were found next to trees with low or medium infestation levels (Fig. 2). The percentage of infested nuts varied significantly among cultivars $(H=40.3 ; \mathrm{df}=24$; $P=0.020$ ), ranging from $2 \%$ ('Siciliana' or 'Racinante G') to $89 \%$ ('Butler'; Table 1). Filbertworm infestation also differed significantly among the seven cultivars represented by three or more trees $(F=24.3, \mathrm{df}=6, P<$ $0.001)$. 'Siciliana' had the lowest percentage of infested nuts $(6 \% \pm 2 \%)$, whereas 'Cosford' nuts showed the highest percent of infestation $(77 \% \pm 7 \%)$.

Average shell thickness for the 17 sampled cultivars (19 trees) varied significantly among cultivars $(H=451.3 ; \mathrm{df}=16 ; P<0.001)$. The percentage of filbertworm infestation significantly increased with decreasing shell thickness at the basal scar (micropyle: $r=-0.799, P<$ 0.001 ; thickest point: $r=-0.665, P=0.004$; Fig. $3 \mathrm{~A}-\mathrm{B})$. The thickness of the nut side wall, on the other hand, did not significantly affect filbertworm infestation levels $(r=-0.399$, $P=0.113$; Fig. 3C). The thickest shells, with on average 1.02 to $1.25 \mathrm{~mm}$ at the micropyle, belonged to 'Siciliana' (accessions labeled 'Locale di Piazza Armerina', 'Avellana Speciale', and 'Minnolara'), which also had the lowest filbertworm infestation (Table 1). 'Frango 2', 'Casina', and 'Daviana', which had the thinnest shells with micropyles nearly half as thick as in 'Siciliana', exhibited very high infestation levels $(76 \%, 55 \%$, and $82 \%$, respectively). The highest proportion of infested nuts $(89 \%)$ was found in 'Butler', which also had relatively thin basal scars (Table 1).

Because 'Siciliana' accessions showed extreme values for filbertworm infestation rate as well as nut shell thickness, data for these accessions were removed from analysis to see if the correlation remains significant among all other cultivars. Without the 'Siciliana' accessions data, the correlation between infestation

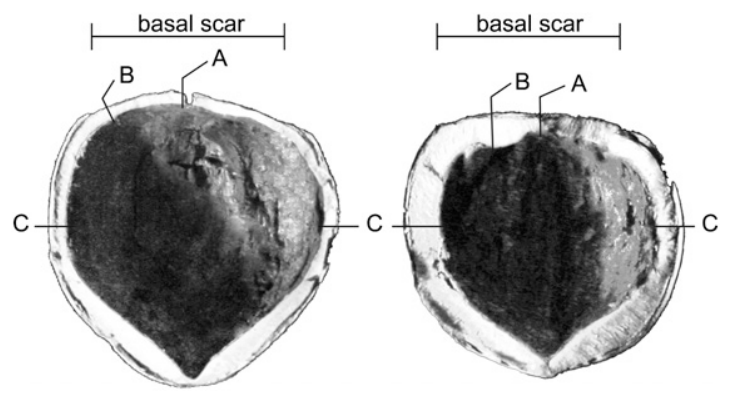

Fig. 1. Cross-sections of 'Daviana' (left) and 'Siciliana' (right) hazelnut shells showing the positions for shell thickness measurements at the basal scar (A, micropyle, the thinnest point; $\mathbf{B}$, the thickest point) and at the nut side walls (C). The basal scar is the area of the shell that attaches the developing nut to the husk. The left image shows the exit hole of a filbertworm larva through the micropyle (adjacent to measuring point $\mathbf{A}$ ).

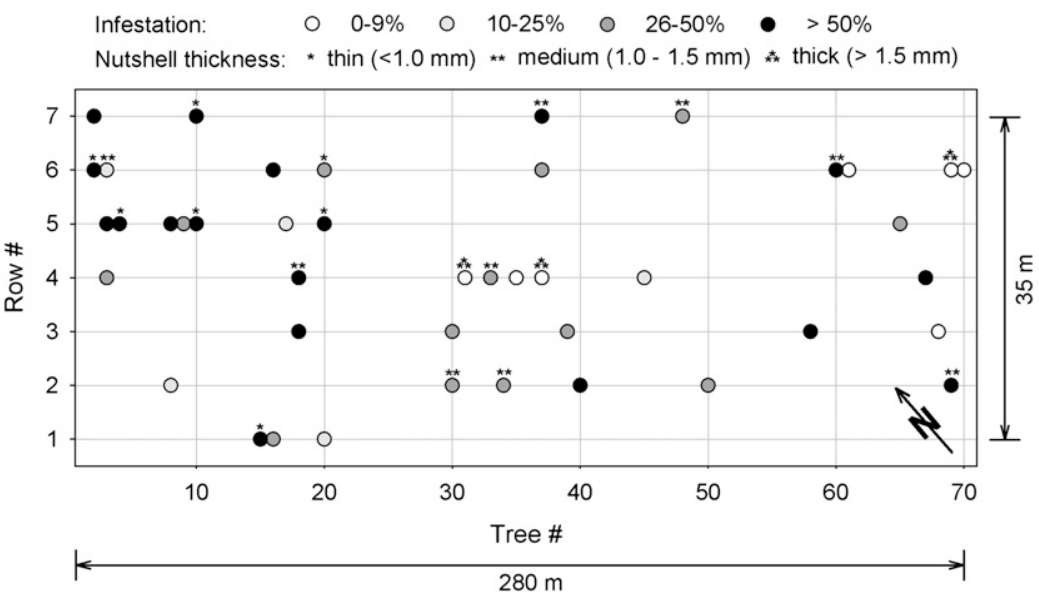

Fig. 2. Physical layout of the hazelnut planting at the USDA National Clonal Germplasm Repository in Corvallis, OR, with the distribution of sampled trees. Trees are rated for their percentage of filbertworm-infested nuts (circle shade) and average overall shell thickness (number of asterisks, see legend). Not displayed in this figure is tree row 17 with the accession Gironenc Colldejou (cultivar Segorbe) with $60 \%$ infestation and medium shell thickness. Shell thickness was not measured for trees without asterisks.

and shell thickness remained significant for the micropyle $(r=-0.723, P=0.002)$ as well as the maximum thickness of the basal scar $(r=-0.502, P=0.047)$.

\section{Discussion}

Hazelnut cultivars have been known to display differences in susceptibility to filbertworm (Dohanian, 1940, 1944). Our data indicate that the degree of filbertworm infestation is correlated with shell thickness and that hazelnut cultivars with thin shells, specifically at the basal scar, tend to have more infested nuts than cultivars with thicker shells. For example, trees of 'Siciliana' with the thickest shells displayed extremely low infestation rates $(2 \%$ to $15 \%)$ in contrast to 'Daviana', which had the thinnest measured shells and a very high percentage of infested nuts $(82 \%)$. Both pollenizers 'Butler' and 'Daviana' had 2.6 times as many infested nuts as their main cultivar counterparts 'Ennis' and 'Barcelona', respectively, confirming a report from Dohanian (1944) stating that filbertworm particularly favored the pollenizer 'Daviana' at a ratio of 3:1 when compared with 'Barcelona'. 'Barcelona' and 'Ennis', the two most important hazelnut varieties grown in Oregon (U.S. Department of Agriculture, NASS 2008), displayed intermediate shell thickness and filbertworm infestation among the cultivars tested. Shell thickness measurements for both cultivars at the NCGR were similar to data reported from Italy where 'Barcelona' and 'Ennis' shells were reported to be $1.62 \pm 0.24$ and 1.13 to $1.24 \mathrm{~mm}$ thick, respectively (Guidone et al., 2007; Valentini et al., 2006).

How exactly thicker shells lead to lower infestation is not known. Neonate larvae typically enter a nut by chewing through the micropyle (Thompson, 1941), the thinnest and softest part of the nut through which it receives nutrients from the tree. Thompson (1941) reports that filbertworm entry into the nut is not always accomplished and that often the larvae perish before gaining entrance and occasionally migrate to another nut. Thicker shells, specifically the basal scar area around the micropyle, are possibly more difficult and time-consuming for neonate filbertworm larvae to penetrate. Our data indicate that already small increases in thickness at the micropyle correlate with a decrease in the percentage of infested nuts.

In addition to shell thickness, shell hardening can contribute to plant resistance against insect pests. Early nut development in hazelnuts was described as a resistance factor to attacks of the nut weevil, Curculio nucum (Coleoptera: Curculionidae) (Guidone et al., 2007). The authors found that hazelnut varieties with earlier hardening shells are less susceptible to weevils than varieties with late hardening shells, whereas shell thickness at harvest was not correlated with infestation. In macadamia nuts, cultivars with thicker shells show significantly lower percent kernel damage from the tropical nut borer, Hypothenemus obscurus (Coleoptera: Scolytidae), than cultivars with thinner shells (Jones et al., 1992). 

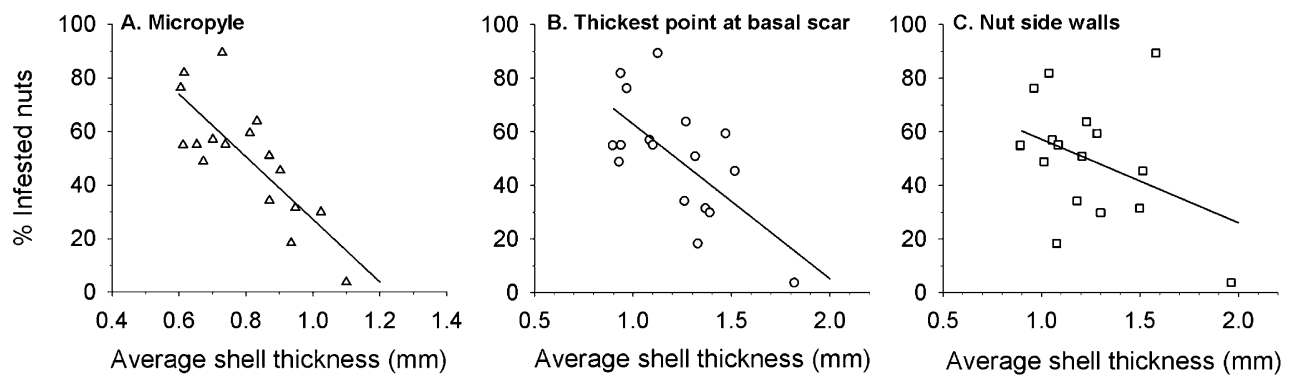

Fig. 3. Relationship between percent filbertworm-infested nuts and average shell thickness in 17 hazelnut cultivars at (A) the thinnest point at the basal scar (micropyle), $(\mathbf{B})$ the thickest point at the basal scar, and $(\mathbf{C})$ the sides of the nut. Regression lines for $(\mathbf{A})$ and $(\mathbf{B})$ are significant $(P<0.05 ;$ A: $y=-116.875 x+$ 144.014, B: $y=-57.724 x+120.632)$.

Both Coleopteran species, however, rarely attack nuts through the micropyle. Entry through the softer micropyle could be the reason why shell hardening does not seem to reduce the ability of filbertworm larvae to penetrate and establish inside a nut. In an abandoned Oregon hazelnut orchard, filbertworm populations were found to infest nuts until late September (Walton and Chambers, unpublished data) long after the shells have hardened, which typically happens in July (Guidone et al., 2007; Thompson, 1979).

This study focused on shell thickness as one possible plant resistance mechanism. Other factors that could impact the probability of filbertworm infestation may include properties of the husk or female preference for or repellence from certain cultivars for oviposition, e.g., as a result of olfactory, tactile, or visual stimuli. The behavioral response of female filbertworm to environmental cues is still mostly unknown. In regard to plant properties, hazelnut husks appear sticky as a result of the presence of glandular trichomes, and this stickiness of the husks varies among cultivars (S.A. Mehlenbacher, personal communication). Glandular trichomes confer resistance to insect pests in other crop plants such as potato, alfalfa, and tomato (Flanders et al., 1992; Ranger and Hower, 2001; Simmons et al., 2003). It is possible that hazelnut husks that appear to be stickier as a result of increased presence of glandular trichomes and/or more secretion reduce the mobility of neonate filbertworm larvae and thus, their chance of entering a nut.

To obtain a more complete understanding of plant resistance to filbertworm infestation and its underlying mechanisms, more nut and husk characteristics need to be examined as well as filbertworm oviposition and neonate larval behavior in response to cultivar characteristics. Further studies should include new hazelnut cultivars such as 'Lewis', 'Yamhill', and 'Jefferson' that have been selected in Oregon for their resistance to eastern filbert blight, a detrimental fungal disease of hazelnut trees (Mehlenbacher et al., 2000, 2009, 2011). Growers and plant breeders may be able to use knowledge from this and subsequent studies to modify management programs and improve cultivar selection. As common pollenizers in Oregon, both 'Daviana' and 'Butler' may require special considerations as a result of their high susceptibility to filbertworm, for example in terms of pest management or sorting of harvested nuts. Growing filbertworm-resistant hazelnut cultivars with thicker shells may be beneficial in terms of reduced pesticide use and environmental impact. In the producer's interest, however, these benefits need to be carefully weighed against potential costs such as dislike by consumers, increased cost of cracking thick-shelled nuts, and less favorable kernel-to-shell ratios.

\section{Literature Cited}

AliNiazee, M.T. 1983. Pest status of filbert (hazelnut) insects: A 10-year study. Can. Entomol. 115: $1155-1162$.

AliNiazee, M.T. 1998. Ecology and management of hazelnut pests. Annu. Rev. Entomol. 43: 395-419.

AliNiazee, M.T., and A. Kelly. 1981. Biology and control of the filbertworm, Melissopus latiferreanus. Proc. Nut Grow. Soc. Or. Wash. B.C. 66:101-103.

Boccacci, P., A. Akkak, and R. Botta. 2006. DNA typing and genetic relations among European hazelnut (Corylus avellana L.) cultivars using microsatellite markers. Genome 49:598-611.

Dohanian, S.M. 1940. Melissopus latiferrreanus as a pest of filberts in the Northwest. J. Econ. Entomol. 33:852-856.

Dohanian, S.M. 1944. Control of filbert worm and filbert weevil by orchard sanitation. J. Econ. Entomol. 37:764-766.

FAOSTAT. 2010. Food and Agriculture Organization of the United Nations. TradeSTAT Hazelnut Export Quantity 2000-2007. 30 Aug. 2010. $<$ http://faostat.fao.org/site/535/DesktopDefault. aspx ?PageID $=535 \#$ ancor $>$.

Flanders, K.L., J.G. Hawkes, E.B. Radcliffe, and F.I. Lauer. 1992. Insect resistance in potatoes: Sources, evolutionary relationships, morphological and chemical defenses, and ecogeographical associations. Euphytica 61:83-111.

Gantner, M. 2005. Susceptibility of large-fruited hazel cultivars grown in Poland to major pest and their crop productivity. Acta Hort. 686: 377-384.

Gökirmak, T., S.A. Mehlenbacher, and N.V. Bassil. 2009. Characterization of European hazelnut (Corylus avellana) cultivars using SSR markers. Genet. Resour. Crop Ev. 56:147-172.

Guidone, L., N. Valentini, L. Rolle, G. Me, and L. Tavella. 2007. Early nut development as a resistance factor to the attacks of Curculio nuсum (Coleoptera: Curculionidae). Ann. Appl. Biol. 150:323-329.

Jones, V.P., L.L. Burnam-Larish, and L.C. Caprio. 1992. Effect of harvest interval and cultivar on damage to Macadamia nuts caused by Hypothenemus obscurus (Coleoptera: Scolytidae). J. Econ. Entomol. 85:1878-1883.
Julian, J.W., C.F. Seavert, and J.L. Olsen. 2008. Orchard economics: The costs and returns of establishing and producing hazelnuts in the Willamette Valley. Oregon State University Extension Service EM 8748-E.

Lagerstedt, H. 1980. 'Ennis' and 'Butler' filberts. HortScience 15:833-835.

Mehlenbacher, S.A., A.N. Azarenko, D.C. Smith, and R. McCluskey. 2000. 'Lewis' hazelnut. HortScience 35:314-315.

Mehlenbacher, S.A., D.C. Smith, and R. McCluskey. 2009. 'Yamhill' hazelnut. HortScience 44 845-847.

Mehlenbacher, S.A., D.C. Smith, and R.L. McCluskey. 2011. 'Jefferson' hazelnut. HortScience 46:662-664.

Olsen, J. 2002a. Growing hazelnuts in the Pacific Northwest. Oregon State University Extension Circular EC 1219.

Olsen, J. 2002b. Oregon State University's Integrated Pest Management Program for the Oregon Hazelnut Industry. HortTechnology $12: 623-625$

Pinkerton, J.N., K.B. Johnson, S.A. Mehlenbacher, and J.W. Pscheidt. 1993. Susceptibility of European hazelnut clones to eastern filbert blight. Plant Dis. 77:261-266.

Ranger, C.M., and A.A. Hower. 2001. Role of the glandular trichomes in resistance of perennial alfalfa to the potato leafhopper (Homoptera: Cicadellidae). J. Econ. Entomol. 94:950-957.

Robinson, R.A. 1996. Return to resistanceBreeding crops to reduce pesticide resistance. agAccess Davis, California \& International Development Research Center, Ottawa, Canada.

Simmons, A.T., G.M. Gurr, D. McGrath, H.I Nicol, and P.M. Martin. 2003. Trichomes of Lycopersicon spp. and their effect on Myzus persicae (Sulzer) (Hemiptera: Aphididae). Aust. J. Entomol. 42:373-378.

Thompson, B.G. 1941. The control of the filbert moth. Agricultural Experiment Station, Oregon State College, Circular of Information No. 231.

Thompson, M.M. 1979. Growth and development of the pistillate flower and nut in 'Barcelona' filbert. J. Amer. Soc. Hort. Sci. 104:427-432.

U.S. Department of Agriculture NASS. 2008. National Agricultural Statistics Service. Hazelnut tree report for 2008. U.S. Dept. Agr., Oregon

U.S. Department of Agriculture NASS. 2010. National Agricultural Statistics Service. Noncitrus fruits and nuts 2009 summary. U.S. Dept. Agr., Oregon.

USDA-NPGS. 2011. Summary statistics of Corylus collection by species. National Plant Germplasm System. 15 Feb. 2011. <http://www.ars-grin.gov/ cgi-bin/npgs/html/stats/genus.pl?Corylus $>$.

Valentini, N., L. Rolle, C. Stévigny, and G. Zeppa. 2006. Mechanical behaviour of hazelnuts used for table consumption under compression loading. J. Sci. Food Agr. 86:1257-1262. 